\title{
Strategies for COVID-19 transmission control and mitigation in a psychiatric hospital in Mexico
}

\author{
Guillermo León-González, ${ }^{1}$ Odón A. Pavón-Gutiérrez, ${ }^{2}$ Carlos Téllez-Santillán, ${ }^{3}$ \\ Francisca Sánchez-Carmona ${ }^{4}$ and Karina Yáñez-Castañeda * \\ ${ }^{1}$ Directorate; ${ }^{2}$ Sub-directorate; ${ }^{3}$ Medical Sub-directorate; ${ }^{4}$ Psychology Department. Hospital Psiquiátrico "José Sayago", State of Mexico, Mexico
}

\begin{abstract}
In the context of the emerging COVID-19 pandemic, one of the great challenges is to generate effective strategies for the control of nosocomial infections, specifically in psychiatric hospitals with populations considered at risk (older adults or individuals with comorbidities). This article describes the strategies for prevention, containment and treatment of infection transmission implemented during a COVID-19 outbreak that occurred in July 2020 in a psychiatric hospital of the State of Mexico. The population was comprised by women with prolonged hospital stay (mean $=24$ years), mostly geriatric (mean $=64$ years), with various psychiatric disorders and comorbidities. In total, 19 COVID-19-positive cases were diagnosed, out of which thirteen had mild symptoms and six were asymptomatic. There were no alterations in mental state, psychiatric symptoms or underlying diseases. Algorithms were developed for the management and treatment of suspected/confirmed COVID-19 cases. Finally, the generation of comprehensive strategies, quick and timely actions, as well as adequate management of human resources favoring interdisciplinary work, were deemed to have contributed to contain and mitigate the COVID-19 outbreak, which constitutes a precedent in the psychiatric field with institutionalized patients.
\end{abstract}

KEY WORDS: COVID-19. Psychiatric hospital. Prevention and control. Mental disorders.

\section{Estrategias de control y mitigación de contagio por COVID-19 en un hospital psiquiátrico en México}

\section{Resumen}

En el contexto de la emergente pandemia de COVID-19, uno de los grandes desafíos es generar estrategias eficaces de control de infecciones nosocomiales, específicamente en hospitales psiquiátricos con población considerada de riesgo (adultos mayores o con comorbilidades). En el presente artículo se describen las estrategias de prevención, contención y tratamiento de contagio, a partir de un brote de COVID-19 ocurrido en julio de 2020 en un hospital psiquiátrico del Estado de México. La población estuvo constituida por mujeres con estancia hospitalaria prolongada (media = 24 años), en su mayoría geriátricas (media $=64$ años), con trastornos psiquiátricos diversos y comorbilidades. En total se diagnosticaron 19 casos positivos de COVID-19, de los cuales 13 cursaron con sintomatología leve y seis resultaron asintomáticos. No se presentaron alteraciones en el estado mental, en la sintomatología psiquiátrica ni en las enfermedades de base. Se realizaron algoritmos para el manejo y tratamiento de los casos sospechosos o confirmados de COVID-19. Finalmente, se consideró que la generación de estrategias integrales, acciones rápidas y oportunas, así como una adecuada gestión de recursos humanos favorecedora del trabajo interdisciplinario contribuyeron a contener y mitigar el brote de COVID-19, constituyéndose en un precedente en el ámbito psiquiátrico con pacientes institucionalizadas.

PALABRAS CLAVE: COVID-19. Hospital psiquiátrico. Prevención y control. Trastornos mentales.

\footnotetext{
Correspondence:

Date of reception: 13-11-2020

*Karina Yáñez-Castañeda

Date of acceptance: $10-12-2020$

E-mail: unidaddeinvestigacionhpjs@gmail.com

DOI: $10.24875 / G M M . M 21000588$

Gac Med Mex. 2021;157:443-447

Contents available at PubMed

www.gacetamedicademexico.com

0016-3813/@ 2021 Academia Nacional de Medicina de México, A.C.. Published by Permanyer. This is an open access article under the CC BY-NC-ND license (http://creativecommons.org/licenses/by-nc-nd/4.0/).
} 


\section{Introduction}

Coronavirus disease-19 (COVID-19) was first identified as an outbreak of respiratory disease in the city of Wuhan, Hubei province, China. ${ }^{1}$ Given the spread of the disease, on January 30,2020 , the World Health Organization declared a global health emergency, and on March 11 of the same year, declared COVID-19 to be a pandemic.

In this context, containing infection transmission in hospital environments has been quite a challenge, especially in psychiatric hospitals, given the cognitive impairment of patients, coupled with low awareness on the risk and prolonged stay. ${ }^{2}$ In addition, the presence of preexisting chronic conditions increases the probability of developing more serious symptoms, ${ }^{3,4}$ specifically when there is diabetes mellitus, hypertension and chronic obstructive pulmonary disease. ${ }^{5,6}$

The emergent nature of this pandemic hindered a timely reaction to the spread of the virus, and COVID-19 outbreaks in no time started occurring in psychiatric hospitals, ${ }^{7}$ where the main risk factors for nosocomial infection were ward overcrowding and poor response of patients due to their mental condition. ${ }^{8}$ This has brought to light the existence of a gap in epidemic response protocols, and it is therefore recommended to learn from previous experience ${ }^{9}$ in other countries, where the measures implemented in situations of epidemiological outbreaks for preventing subsequent nosocomial infections have been reported. ${ }^{10}$

In Mexico, government institutions ordered measures aimed at COVID-19 prevention and mitigation in psychiatric hospitals. ${ }^{11}$ However, positive cases of the disease have been reported that have even resulted in deaths. ${ }^{12}$ Most government guidelines require for adjustments to be made according to the needs of the type of population institutionalized at each hospital and, for this reason, the purpose of this article is to describe the strategies for disease transmission prevention, containment and treatment, based on the occurrence of a COVID-19 outbreak in a public psychiatric hospital of the State of Mexico, where 171 women with various mental disorders, aged between 21 and 99 years (although most were older than 60 years), do reside. The users cohabit in "villas", which are spaces intended for 12 users on average, and that include four bedrooms, one bathroom per bedroom, a common area, a dining room and a medical control area.

\section{Prevention strategies}

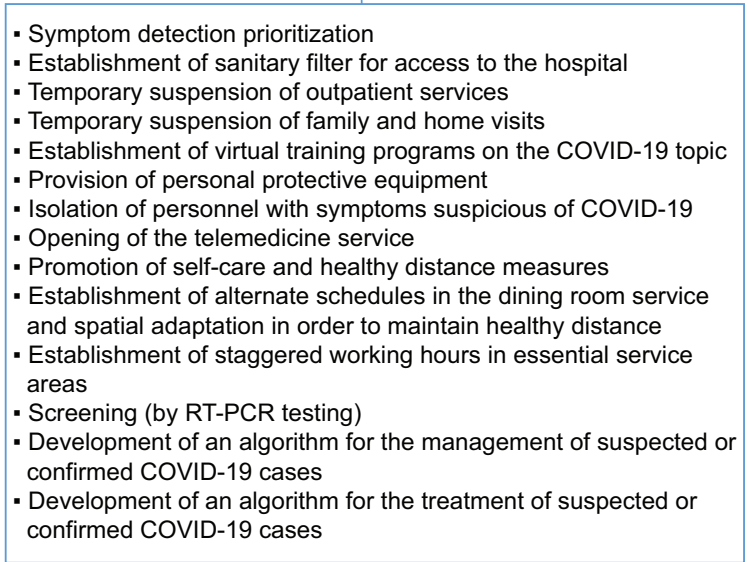

Figure 1. Prevention strategies implemented in a psychiatric hospital in the face of the COVID-19 outbreak.

\section{Prevention measures}

In this regard, adjustments were made to the guidelines established by the Ministry of Health in coordination with Psychiatric Care Services and the National Council of Mental Health. New strategies based on the concept of harm reduction, adjusted in response to the needs of the hospital, were implemented (Fig. 1). Sanitary filters were implemented to allow detecting possible cases of COVID-19 based on the presence of related symptoms. In addition, algorithms were created for the management and treatment of suspected or confirmed cases of COVID-19 infection, which enabled the staff to be prepared for prompt and effective response. Screening tests among the personnel were also carried out, which revealed the existence of confirmed but asymptomatic COVID-19 cases, whereby the possible origin of nosocomial infection was identified.

\section{Containment measures}

In this area, strategies were adopted that allowed mitigating the spread of the virus (Fig. 2). Initially, special areas were reconverted for the care of COVID-19 suspected and confirmed cases, to which only the personnel that was essential for the care of users had access. Said personnel was selected considering those who denoted greater psychological strength for coping with stress and fear, as well as for enduring the dehydration caused by the use of 


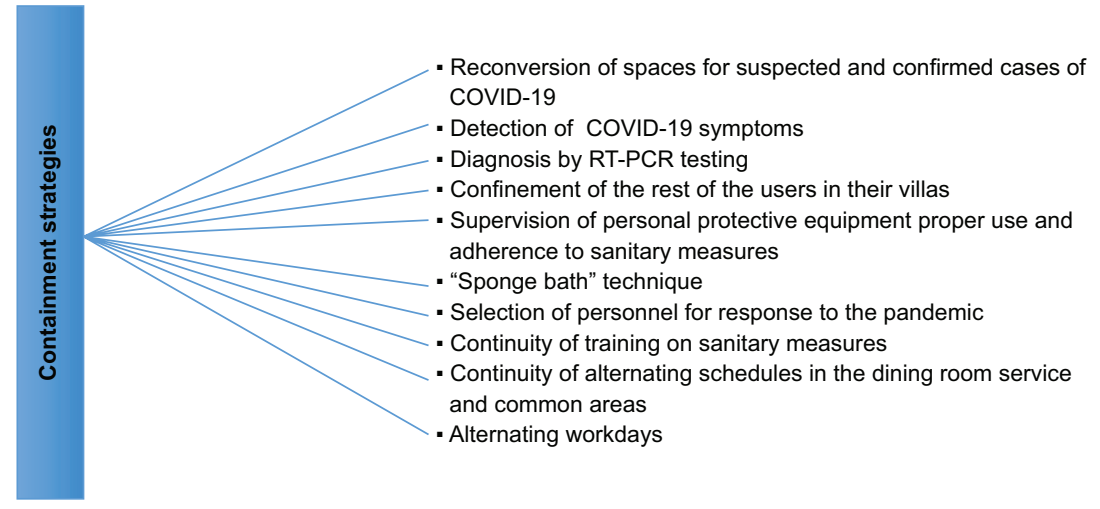

Figure 2. Containment strategies implemented in a psychiatric hospital in the face of the COVID-19 outbreak.

personal protective equipment. In addition, proper use of personal protective equipment and adherence to safe distance and hand hygiene measures was supervised by the rest of the staff. Staggered working hours and alternating workdays were established; specifically, the nursing area established two schedules within a normal duty shift in order for not to wear down the staff and implemented the use of "sponge baths" to avoid an accumulation of gases and vapors that could constitute a source of transmission. At the same time, confinement in villas of the rest of users was indicated, a key action for preventing nosocomial transmission.

In view of this situation, the psychology area implemented occupational therapy and activities aimed at preventing psychiatric and psychological symptoms exacerbation during the confinement. It also generated care programs aimed at the pandemic response teams. In turn, the social work area generated strategies to maintain communication with users' relatives. Finally, these measures helped to lessen the general impact of the pandemic not only on the users but also on the personnel that serves at the psychiatric hospital.

\section{Management and description of cases}

On July 1, 2020, four cases considered suspicious of COVID-19 were reported when they had fever without apparent cause detected; subsequently, two cases whose cause was related to bacterial infections were ruled out. As a result, the test for SARS-CoV-2 was carried out by real-time polymerase chain reaction (RT-PCR, thus confirming the first two positive cases, which had fever). In addition, RT-PCR testing was performed on all the women the first positive patients cohabited with in the villa, even if they had no symptoms. During the next 5 days, a total of 19 women with a confirmed diagnosis ( $11.11 \%$ of total population) did accumulate, who were placed in isolation from July 3 to 23. Although action protocols indicate 10-day isolation periods, maintaining this measure for 21 days was decided in order to avoid in as much as possible a second group of infection transmission.

Subsequently, a systematic review of 19 medical records was carried out in order to assess vital signs (temperature, blood pressure, heart rate, respiratory rate and oxygen saturation) and laboratory tests were reviewed. In addition, the comorbidities the users have and the medication they receive were considered according to psychiatric and medical diagnoses before the development of COVID-19 infection (Table 1).

COVID-19-positive users were mostly geriatric patients, aged between 43 and 95 years (mean = 64 years), had a hospital stay time ranging from 7 months to 61 years (mean $=24$ years) and were provided management according the algorithm for the treatment of suspected or confirmed COVID-19 cases, mentioned in the prevention section. No significant alterations were found in temperature (mean $=36.2 \pm$ 0.32 ), blood pressure (mean $=105 / 66 \pm 10.645$ ), heart rate $($ mean $=73.13 \pm 6.04)$ or respiratory rate (mean $=$ $19.51 \pm 0.46$ ) general figures. Laboratory tests showed values within normal ranges. Nine cases had arterial oxygen saturation $<90$ at alternate periods, which was more acute during the evening-night. In two cases, $3 \mathrm{~L} / \mathrm{min}$ of oxygen by nasal cannula was required. In total, 13 cases had mild symptoms (specifically, fever, arthralgia and hypoxemia) and six were asymptomatic. The cases did not show mental state alterations, psychiatric symptoms or underlying conditions. 
Table 1. Psychiatric diagnosis, comorbidities, pharmacological history and COVID-19 symptoms. Clinical characteristics of COVID-19-diagnosed users

\begin{tabular}{|c|c|c|c|c|c|c|c|}
\hline Psychiatric diagnosis & $\mathrm{n}$ & Comorbidities & n & Pharmacological history & $n$ & COVID-19 symptoms & $n$ \\
\hline Paranoid schizophrenia & 2 & Epilepsy & 2 & Psychotropic drugs & 19 & Arthralgia & 1 \\
\hline Hebephrenic schizophrenia & 1 & Diabetes mellitus 2 & 1 & Antidiabetic drugs & 1 & Fever & 2 \\
\hline Residual schizophrenia & 2 & Obesity & 2 & Vasoprotective drugs & 1 & Low-grade fever & 1 \\
\hline Profound mental retardation & 3 & CMD & 1 & Anticholinergic drugs & 4 & Hypoxemia & 9 \\
\hline Severe mental retardation & 6 & Gonarthrosis & 1 & Other & 12 & & \\
\hline Moderate mental retardation & 3 & COPD & 1 & & & & \\
\hline Bipolar disorder & 1 & Chronic gastritis & 2 & & & & \\
\hline Mixed dementia & 1 & Lymphoma & 1 & & & & \\
\hline
\end{tabular}

\section{Conclusions}

The emerging context of the COVID-19 pandemic has meant the breakdown of many paradigms with regard to the health-disease process and, consequently, numerous guidelines have had to be adapted in order to provide effective care.

In this sense, in the case herein described, health personnel who had the disease asymptomatically caused an outbreak, even with the prevention measures established at the beginning of the pandemic. Consequently, planning that contemplates comprehensive strategies based on prevention, containment, mitigation and prompt establishment of action protocols will enable confronting the challenges resulting from the presence of COVID-19 or any emerging disease.

Thus, the generated strategies, as well as the algorithms for the management and treatment of patients designed by the multidisciplinary team, establish a precedent in the psychiatric field with institutionalized patients, which serves as a basis for future emerging experiences.

Adequate management of human resources and contributions by the multidisciplinary team were essential for the aforementioned strategies successful implementation.

It is important mentioning that, despite the conditions of psychiatric diseases, coupled with the presence of comorbidities in the described population, the course of COVID-19 infection did not generate substantial systemic harm. Contrary to previous reports, no alterations were observed in the underlying disease or in the symptoms caused by COVID-19 infection, and no emergency care measures or hospitalization were therefore required. This fact deserves to be studied in depth, since it suggests that some protective factor allows patients with these characteristics to go through this and other diseases without complications.

Finally, COVID-19 appeared as a window of opportunity for innovating and improving the processes that allow reducing the rate of infections, understanding that the described measures will become permanent, given that their effectiveness was shown by minimizing the harm caused by the pandemic.

\section{Conflict of interests}

There are no conflicts of interest.

\section{Funding}

The authors did not receive any funding for this research.

\section{Ethical disclosures}

Protection of human and animal subjects. The authors declare that no experiments were performed on humans or animals for this research.

Confidentiality of data. The authors declare that they followed the protocols of their work center on the publication of patient data.

Right to privacy and informed consent. The authors declare that no patient data appear in this article. 


\section{References}

1. Cennimo D, Olsen K. Coronavirus Disease 2019 (COVID-19): practice Essentials, Background, Route of Transmission. Medscape; 2021.

2. Yao H, Chen JH, Xu YF. Patients with mental health disorders in the COVID-19 epidemic. Lancet Psychiatry. 2020;7:e21.

3. Niu S, Tian S, Lou J, Kang X, Zhang L, Lian H, et al. Clinical characteristics of older patients infected with COVID-19: a descriptive study. Arch Gerontol Geriatr. 2020;89:104058.

4. Richardson S, Hirsch JS, Narasimhan M, Crawford JM, McGinn T, Davidson KW, et al. Presenting characteristics, comorbidities, and outcomes among 5700 patients hospitalized with COVID-19 in the New York City area. JAMA. 2020;323:2052-9.

5. Huang I, Lim MA, Pranata R. Diabetes mellitus is associated with increased mortality and severity of disease in COVID-19 pneumonia a systematic review, meta-analysis, and meta-regression. Diabetes Metab Syndr. 2020;14:395-403.
6. Yang J, Zheng Y, Gou X, Pu K, Chen Z, Guo Q, et al. Prevalence of comorbidities and its effects in patients infected with SARS-CoV-2: a systematic review and meta-analysis. Int J Infect Dis. 2020;94:91-5.

7. Ji H, Liu L, Huang T, Zhu Y. Nosocomial infections in psychiatric hospitals during the COVID-19 outbreak. Eur J Psychiat. 2020;34:177-9.

8. Chen J, Xiong M, He Z, Shi W, Yue Y, He M. The enclosed ward management strategies in psychiatric hospitals during COVID-19 outbreak. Global Health. 2020;16:53.

9. Hsu ST, Chou LS, Chou FH, Hsieh KY, Chen CL, Lu WC, et al. Challenge and strategies of infection control in psychiatric hospitals during biological disasters from SARS to COVID-19 in Taiwan. Asian J Psychiatr. 2020;54:102270.

10. Gaspard P, Mosnier A, Gunther D, Lochert C, Larocca S, Minery P, et al. Influenza outbreaks management in a French psychiatric hospital from 2004 to 2012. Gen Hosp Psychiatry. 2014;36:46-52.

11. Lineamientos Generales Para la Mitigación y Prevención de COVID-19 en Los Hospitales Psiquiátricos. Mexico: Gobierno de México; 2020.

12. Son 3 Muertos por Brote de Covid-19 en Siquiátrico del Edomex: $\mathrm{CNDH}$ La Jornada; 2020. 